Coit-9011:16--10

UCRL-JC-103726

PREPRINT

\title{
Container Materials for High-L.evel \\ Nuclear Waste at the \\ Proposed Yucca Mountain Site
}

\author{
R. Daniel McCright
}

Prepared for Submittal to Materials Research Society, Scientific Basis for Nuclear Waste Management XiV, Boston, MA

November 26-28, 1990

Manuscript Date: November 1990 Publication Date: May 1991

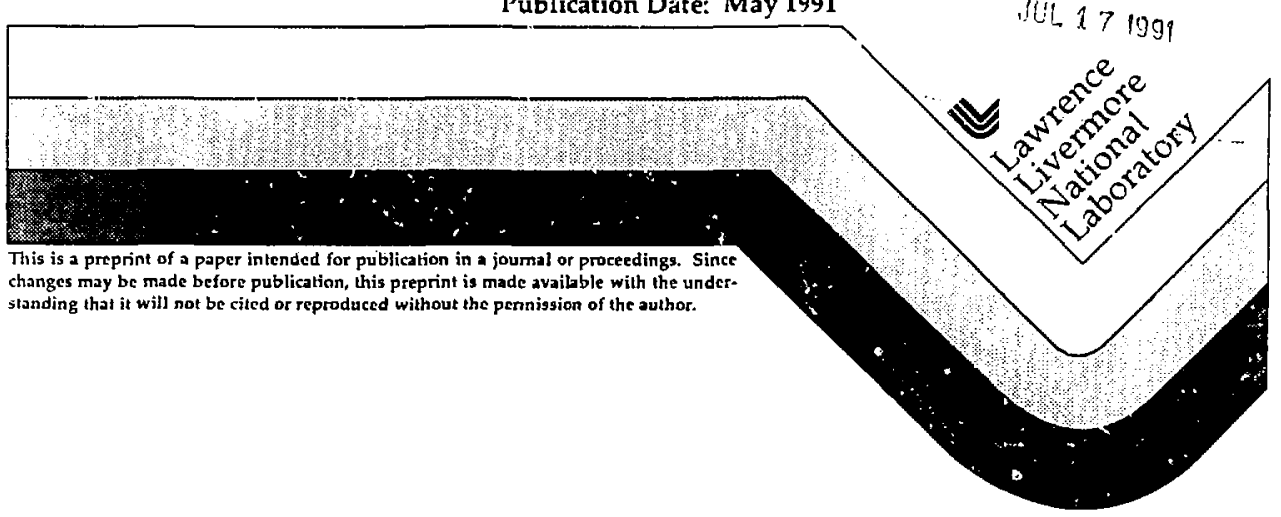

\section{MASER}


DISCLAIMER

This docurnent was prepaied al an octonnt of work spensored by an axtmcy of the

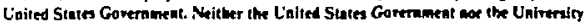
of Californis nor any of their employees, makes any wartanty. expeess or implled, or essumes any lezal liability or essponsibility for the aceurecy, completeneas. or asefur-

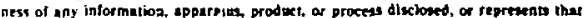
its use wauld not infringe privately owned inges. Reference herein to any apeethe commercial products, process, or servlce by trade name, trademark, manufecturer, or otherwise, does not necesurily constitute or imply its endorsciment, recommendation, of Evoring by the Uniled Stales Governmenl of the Unirenity of Calliornia. The rhews and apinions of euthon expresued herein to nat mecenatily save or ceflect

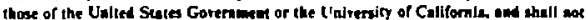
be used for adrestisint of protiect edodoement purpesses. 
CONTAINER MATERIALS FOR HIGH-LEVEL NUCLEAR WASTE AT THE PROPOSED YUCCA MOUNTAIN SITE

UCRL-JC-- 103726

R. DANIEL McCRIGHT

DE91 015298

Lawrence Livermore National Laboratory, P.O. Box 808, Livermore, CA 94550 USA

\section{ABSTRACT}

Candidate container materials for high-level nuclear waste packages to be emplaced at the proposed Yucca Mountain repository site are being considered for their long-term resistance to corrosion, oxidation, embrittlement and other kinds of degradation. Selection criteria have been established, and a method has been developed for recommending a material for advanced container design activities. An extensive compilation of the degradation phenomena for six candidate materials is complete, and further studies have begun on the degradation modes affecting additional candidate materials. Phenomenological models for predicting container degradation rates are being advanced for environmental conditions applicable to Yucca Mountain. An experimental program is underway to evaluate the susceptibility of container materials to localized corrosion, stress corrosion cracking, and enhancement of corrosion and oxidation attack by gamma radiation. Initial evaluations of container fabrication and welding processes have identified some processes that appear to alleviate some long-term corrosion susceptibility concerns.

\section{INTRODUCTION}

The United States Department of Energy's (DOE) Yucca Mountain Project (YMP) is investigating the suitability of the Yucca Mountain site for establishing a repository to contain much of the nation's high level nuclear waste. The Lawrence Livermore National L horatory (LLNL) has the responsibility of the "waste package", and this responsibility includes the selection, characterization, and performance analysis of the waste package container materials. The Yucca Mountain site is located on federally owned land in the arid climate of southwestern Nevada. The host rock at this site is tuff, formed teis of millions of years ago by periodic volcanic activity. The tuff was formed in layers; compression and heat has caused some of these layers to weld together. The horizon at which the repository would be located is in a layer of densely welded tuff (Topopah Spring member). The repository would be located in the unsaturated zone, approximately 300 meters below the summit of Yucca Mountain and more than 200 meters above the saturated zone. For more details, a description of the geochemistry and petrology of the environment that would surround the emplaced waste packages has been published [1].

Location of the repository in the unsaturated zone has important implications for the design of the container and the choices of materials. In this respect, the YMP has differed from the basalt and bedded salt repository projects (now discontinued) in the USA and from current projects pursued in other countries. Because there will be no hydrostatic pressure and no steady-state lithostatic pressure acting externally on the container surface, a heavy-walled container is not required for mechanical strength. Because prolonged immersion in an aqueous environment of the vast majority of the containers is not an expected condition, thick-sectioned containers to allow for wastage by corrosion are not considered necessary. However, there is the possibility of contact by aqueous media occurring as a transient condition, and much 
of the focus of this paper is directed toward the consequences of aqueous contact. Thus, for mechanical and chemical considerations, thin-walled containers fabricated from corrosion-resistant materials have been emphasized in the development of waste package designs for the Yucca Mountain repository. Background on container design can be found in the 1984 Conceptual Design report [2].

\section{PRESENT WASTE PACKAGE DESIGNS AND CONFIGURATIONS}

Since the 1984 Conceptual Design Report there have been some minor changes in waste package dimensions. The current conceptual designs are depicted in Figure 1. Two generic kinds of waste packages are planned for emplacement in the repository:

(1) Nuclear waste from the more than 100 operating nuclear power plants in the I.SA will be dispcsea as spent fuel rods (with their cladding) arranged inside the disposal container. The fuel rods may be placed inside the container as intact assemblies (direct from reactor cooling pond or dry storage) arranged within internal partitions in the container. Some consideration is also being given to consolidating sume firel assemblies to reduce the number of disposal containers. It is currently estimated that there will be 25,000 to 30,000 spent fuel waste packages in the repository.

(2) Reprocessed waste is tabricated into a borosilicate glass, melted, and poured into a stainless steel pour canister. This pour canister will then be put inside a disposal container. Most of the reprocessed waste comes from defense projects, and construction of a large-scale facility to handle and vitrify the waste is nearing completion on the Savannah River Site in South Carolina. Additional facilities of this iature are planned at other government-owned sites. There is a small amount of reprocessed waste that is derived from commercial nuclear power plants, anri a facility for handling and vitrifying this waste is under construction at the West Valley site in upstate New York. This waste will also be poured into a stainless steel pour canister. Current estimates are that there will be about 14,000 glass waste packages in this repository.

The dimensions given in Figure 1 are for illustration purposes; selection of the final design is still in the future. While the two kinds of waste packages have similar diameters, the spent fuel package is considerably longer than the glass waste package. The length of the spent fuel package shown in Figure 1 accommodates the longest fuel rods. There are two major types oi commercial reactors in use in the USA - PWR and BWR - and severai different reactor designs exist for each of these types. Fuel rod dimensions vary according to reactor type and design. The internal configuration, arrangement, and spacing of partitions are important details of the spent fuel waste package design. Most of the work performed thus far has focused on vertical emplacement of the waste packages with one package emplaced in each borehole. Some consideration is being given to horizontal emplacement, including multiple packages in each borehole. Although the horizontal emplacement may result in less excavation, there appear to be more material-related problems associated with the horizontal configuration. This will be discussed in a later section.

Heat generated by radioactive decay of the waste warms the container and surrounding rock. The temperature of the container is expected to rise to a maximum shortly after emplacement and then slowly decrease as the waste decuys. Spent fuel waste packages will develop higher temperatures than the glass waste packages, but many details of the waste package and repository design (such as power 

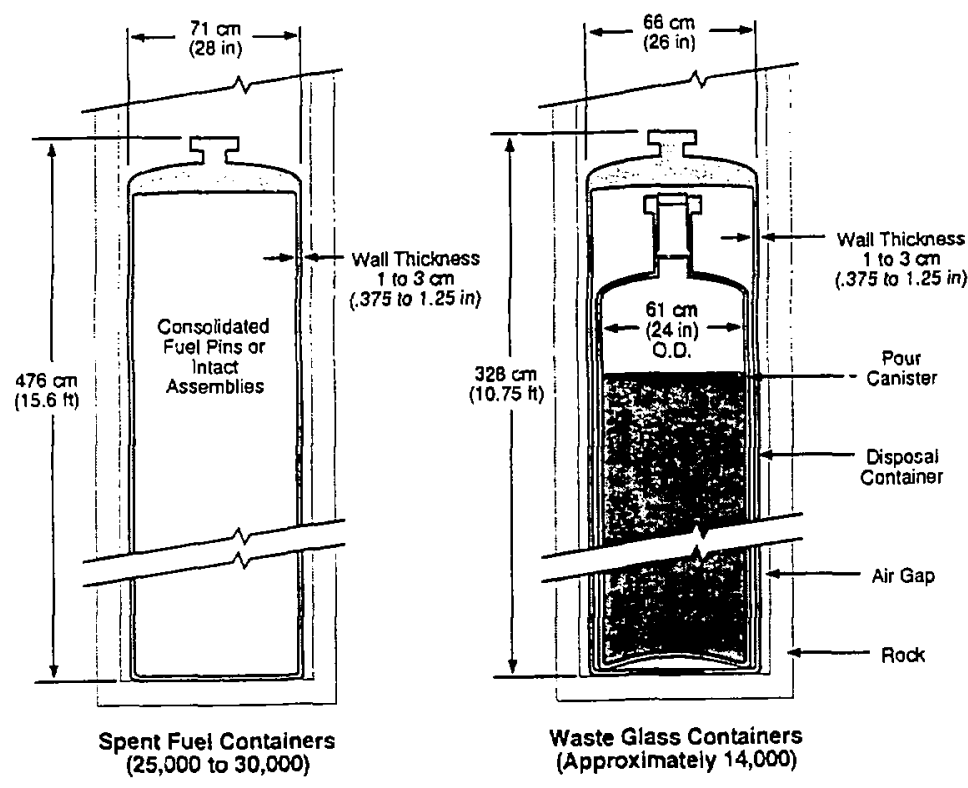

Waste Glass Containers

(Approximately 14,000)

Figure 1

Two types of waste packages will be placed in the repository at the proposed Yucca Mountain site.

loading per container, areal power loading, whether the two kinds of waste packages are co-mingled or separated), as well as characteristics of the waste itself (age of the waste, isotopic content) will determine the peak temperatures and the temperature decay transient. To give a comparative approximation, temperatures as high as $250^{\circ} \mathrm{C}$ may occur on the container surface for spent fuel packages, and as high as $150^{\circ} \mathrm{C}$ for the reprocessed waste packages. Similarly, the initial radiation field is projected to be highest for spent fuel packages $\left(\sim 10^{4} \mathrm{rads} / \mathrm{hr}\right)$ and considerably lower for the glass waste packages.

The thickness of the metal container in the conceptual design is in the range of one to three centimeters. This range allows for some flexibility in compensating for the difference in mechanical strength among the candidate materials and also allows for flexibility in choosing among different processes for fabricating the containers. For instance the bottom of the container and the lid may be thicker than the cylindrical body of the container. Loads imparted during the handling operations are probably the highest that the container will ercounter, and the resulting stress will be concentrated in the "neck" of the container [2]. The contoured container shape and thicker section in this area will help to distribute the stress.

If the Yucca Mountain site is determined to be suitable, a surface handling facility will be constructed at the base of the mountain. At this "hot cell" facility, the waste 
will te encanistered into an empty container shell. The closure weld required to seal the filled container will also be made in the "hot cell", and the completed waste package will then be transported in a shielded cask via a ramp to the repository.

\section{CANDIDATE MATERIALS FOR WASTE PACKAGE CONTAINERS}

The emphasis on containec materials for the YMP has been on corrosion resistant materials. Emplacement of the waste packages in the repository will heat the surrounding atmosphere and rock to vaporize water held in rock pores. The prevailing environmental condition in the repository is exposure to water vapor and atmospheric gases in steadily decreasing thermal and radiation fields as the radioactive waste decays.

To date, the primary emphasis has been on six cardidate materials for the container. These are grouped into two families: (A) iron-hase to nickel base austenitic alloys, specifically AISI 304L and AISI 316L stainless steels and the nickel-rich Alloy 825 (Incoloy 825); (B) copper-base materials, specifically unalloyed oxygen-free copper (CDA 102), 7\% aluminum bronze (CDA 613), ana 70/30 sopper-nickel (CDA 715). Background information on how thesn candidates were selected and evaluated is available [3]. This reference also gives the composition and nominal mechanical properties of the candidate materials.

The probability of water intrusion into the near-container environment continues to receive a great deal of attention, and a number of scenarios are being explored on thic ways water can get to the container and what the consequences of these events will be. All of the candidate materials are believed to have good to excellent corrosion resistance against general aqueous corrosion and low temperature oxidation in the prevailing environmental condition of Yucca Mountain. Also, these materials are all quite ductile, and would not be expected to fail by reasonable mechanical loads and impacts. Their resistance to localized corrosion and to environmentally-assisted eracking phenomena varies among the materials. A lengthy survey ( 8 volumes and an overview) of the performance of these six candidate materials, based on published information in the technical iiterature, has been completed [4]. A comparative evaluation of the candidate materials, with a tentative ranking of the candidate materials in the same alloy family, has also been published [5].

Federal regulations state the performance goals of the container with wording of "reasonable assurance" of "substantially complete containment" for a period of "at least 300 years" and maybe considerably longer. Interpretation of what these words mean with regard to the permitted number of container failures has long heen a source of lively and lengthy discussion. At present, a very conservative view is taken, in the sense of few container failures and a long containment period. Additionally, the effect of a number of low probability but credible scenarios resulting in aggressive chemical conditions occurring in the repository environment are inder consideration. For these reasons, the YMP is exploring additional cancidate materials, particularly materials tnat are even more corrosion resistant (especiaily to localized corrosion and to environmentally assicted cracking; under highly aggressive environmental conditions (e.g. high electrolytic concentrations, low $\mathrm{pH}$, strongly oxidizing electrochemical potentials). These materials inclide a variety of nickel-base alloys, titanium, and dilute titanium-base alloys that could be used for single metal, thin-walled container designs.

As a further step, more robust designs are being considered, at least conceptually. These include: thicker containers of single merals; multiple metal barriers; multiple 
Inetal, ceramic or other nonmetallic barriers; packages with packing material on the outside of the container; and packages with filler materials on the inside of the container. There are obviously many trade-offs to be made between conservatism in design, the gain in assurance for performance predictions, and the practical matters of cost, fabrication, and closure of these more robust configurations. The scope of this paper is linited to discussion of the single-metal, thin-walled container configuration, but it is well to keep the other configurations in mind when discussing the container material concerns.

\section{CONTAINER MATERIAL CONCERNS FOR EMFLACED CONTAINERS}

There are a considerable number of concerns related to possible degradation and failure of the container. These are depicted in Figures $2 \mathrm{~A}$ and $2 \mathrm{~B}$. Figure 2A shows the metallugical and mechanical concerns, while Figure $2 B$ indicates the chemical and environmental concerns. Many of these concerns are, of course, interrelated. It is noted that the problem list is maximized; proper design of the waste package and borehole, choice of container materials and container fabrication and closure processes will eliminate or mitigate some of these performance concerns. For purposes of this discussion, a vertically emplaced container is shown with a liner that partially lines the borehole, a support plate on which the container rests, and a radiation shield plug on top of the borehole. Very little work has been done on these peripheral (to the waste package) components with regard to the design, requirements, configuration, and materials to be used. These components can influence the performance of the waste packaze container.

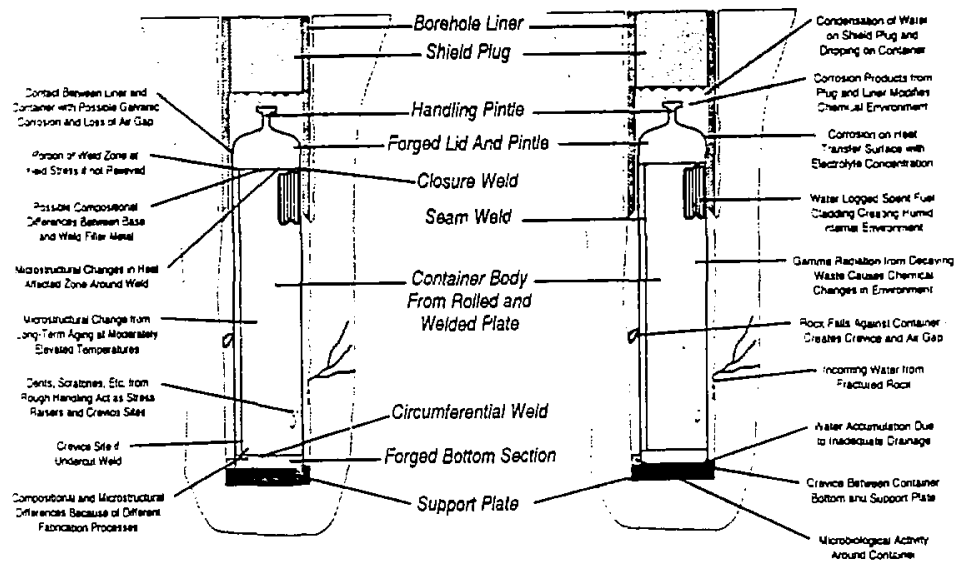

Figure 2A

Metallurgical and mechanical container performance considerations.
Figure 2B

Chemical and environmental container performance considerations. 
As indicated in Figure 2, some assumptions have been made in the container fabrication processes and in the welding processes for closing the container. Let us suppose that the container body is made from plate stock, rolled, and joined in a seam weld. The container bottom is assumed to be made from a forging and welded to the main body. This constitutes the empty "container shell" that, presumably, would be made elsewhere and transported to the surface handling facility, where it would be filied with the waste (spent fuel assemblies or a pour canister contzining glass waste) in the "hot cell". Then, the lid and pintle assembly would be welded onto the assembled package in the hot cell. Because this closure weld has to be made remotely, there are restraints on the processes that can be used as well as on the non-destructive inspection techniques and limitations to any possible post-weld stress relieving or annealing treatments.

Compositional and microstructural differences between parts of the container made by different fabrication processes can establish local galvanic cells in the regions where these parts adjoin (assuming that there is an electrolyte present). If filler weld processes are used, compositional and microstructural inhomogeneities between the filler and the base metal can create a similar galvanic effect; the effect is particularly harmful if the material in the weld is the more anodic member of the couple since the attack will then be concentrated over a small area. Whether filler or autogenous weld processes are used, a heat-affected zone is formed and various microstructural changes can occur in this zone. The width of the zone and the amount of change depends strongly on the alloy composition and many parameters in the welding process (especially the amount and duration of the heat input). Thermal stresses resulting from the heat input, expansion and contraction during the fusion process, and relatively rapid post-weld cooling are important considerations. Some of the microstructural changes are strain-rate dependent. Residual stresses could increase the local stross intensity to a value above the threshold to initiate stress corrosion cracking or a hydrogen-induced cracking (again assuming the presence of a causative environment). Poorly finished welds can serve as crevice sites.

In principle, the "assembly welds" (the seam weld and circumferential weld joining the body to the bottom plate) can be stress relieved and/or annealed to reduce or eliminate the stresses and microstructural differences. Post-weld forming operations can be taken to homogenize the weld region. Autogenous welds eliminate the in homogeneity introduced by the filler. Weld processes, such as friction welding or incrtial welding, eliminate fusion and resolidification and therefore result in greater homogensity.

A variety of container fabrication processes and welding processes were evaluated through a sub-contract effort at Babcock and Wilcox (B\&W). Their work was focused on the operational aspects of the different processes, as well as the effects on container material performance. Inertial welds were made on specimens of some of the candidate materials, and early results were encouraging in obtaining a high degree of homogeneity.

Among the candidate materials, many austenitic stainless steels and nickel base alloys are subject to sensitization in the heat affected zones, making this area susceptible tc intergranular attack or intergranular stress corrosion. The low carbon contents (the " $\mathrm{L}$ grades") and presence of carbide stabilizing elements (e.g. titanium in Alloy 825 ) greatly reduce this possibility. Alloy 825 is often welded with a higher nickel alloy filler material, but as the filler material is more cathodic than 
the base material, there should be little if any enhancement of corrosion in the welded region. Among the copper-base candidate materials, the aluminum bronze appears to be more susceptible to localized attack in the welded region because of the greater galvanic difference between $\mathrm{Cu}$-rich phases and $\mathrm{Al}$-rich phases formed during post-weld solidification. The high thermal conductivity of unalloyed copper requir es high heat input, and this imposes limitations on choices of welding processes. From a materials performance viewpoint, prolonged heating of copper could increase the possibility of oxygen absorption (and resulting embrittlement) from very small amounts present in protective cover gases (arc welding processes). Electron beam welding in a vacuum chamber is the preferred process.

The lengthy thermal decay occurring in the emplaced container may be an advantage for relieving residual stress. The temperatures are probably too low to cause many inetallurgical changes, and while this may not help to ease the in homogereity concerns, it suggests that no new detrimental rtactions should occur. For instance, experimental and theoretical work performed under sub-contract at Ohio State Lniversity showed that there is virtualiy no chance that post-weld low temperature sensitization would occur in 316-types of stair.less steel during the lung times at moderately elevated temperatures, even at high strains. Presumably, the kinetics of many other nucleation and growth-driven transformations would be too slow for changes to occur during the waste containment period.

During container handling and emplacement operations, scratches and other surface defects can subsequently act as local stress raisers and crevice sites, making these areas more prone locations where localized corrosion or stress corrosion could initiate. Althergh ituticeably damaged containers would not be emplaced, the possibility exists that snme defects would not be detected.

Contact between the container and the borehole liner creates a potential galvanic cell if electrocheinically dissimilar metals are used and if an electrolyte is present. If carbon steel were used for the liner, this material will likely be anodic to all of the candidate container materials, and attack should be conined to the liner. This contact will also bridge the air gap between the container and borehole (with or without the liner). The air gap is viewed as a barrier because it wculd prevent any moisture present in the rock matrix from coming into contact with the container. The contact area will also ait as a crevice, and if ferric ions produced by a carbon steel liner accumulate in this area, a potentially damaging electrolyte may be produced.

\section{Chemical and Environmental Considerations}

Figure $2 B$ illustrates the performance concerns that are based on chemical and environmental considerations. The dominant flow mechanism for water is. the repository is believed to be by mitrix flow in the rock. There are some fractures in the rock at the Yucca Mountain site, but water flow through the fracture is believed only possible duriıg relatively infrequent, transient pluvial periods. Heat from the waste package will vaporize the water until the "temperature front" corresponding to the boiling point (about $96^{\circ} \mathrm{C}$ ) retracts to the container. Depending on the type of waste package and the thermal aspects of the waste package and repository design, many of the containers will not reach this temperature until several hundred years after emplacement.

Water entering the near-package environment from rock fractures can accumulate around the container, if drainage around the borehole is not good. The 
contact point between the container bottom and support plate (or whatever the container rests upon) offers an ideal crevice site for localized corrosion initiation. 'The composition of the water has an important bear.ng on the rate and extent of the corrosion. The YMP has considered water from the near-by J-13 well to be representative of water that has been conditioned by contact with the Topopah Spring tuff member. Whether the composition of the J-13 well water truly approximates the water passing through the rock matrix and fractures at the repository elevation needs to be determined during site characterization, and certainly the presence of the waste package and its peripieral components have the potential to modify the water composition. Any residue left from repository cunstruction activity will likewise modify the environment. Discussion of J-13 well water and its relationship to the repository is found in the report by Glassley [1].

Accumulation of water at the bottom of the borehole would favor attack in the inevitable crevice formed between the container bottom and whatever is used to support the waste package. Corrosion attack is mitigated by design of the structure to lessen the severity of the crevice and facilities to improve drainage away from the container. Metal to metal crevices are usually more severe than rock to metal crevices, such as those that could be produced by rock sloughing against the container wall.

As mentioned earlier, the horizontal emplacement configuration is viewed as generating more materials performance concerns than vertical emplacement. Because a borehole liner would have to be used, there is conceivably more contact area between the liner and either the container (if the container rests directly on the liner) or between the container and a conveyance used for emplacement of multiple packages in the same borehole. This increases the concerns for possible crevice corrosion and for galvanic corrosion if dissimilar metals are used.

The shield plug and borehole wall are expected to be cooler than the container. Thus, moisture condensation and accumulation are likely to occur first on these surfaces. As shown in Figure 2B, water dripping from the plug onto the metal container will be conditioned by corrosion products formed on the plug. If the plug were made of cast iron or steel, this water will likely contain ferric ions; depending on which anions are present in the water, this has the potential effect of damaging the container. Ferric salts (especially the chloride) are oxidizing and acid hydrolyzing with the result of favoring pitting attack on most of the candidate materials. Ferric compounds in crevice geometries are aggressive to many metals, and $\mathrm{FeCl}_{3}$ is implicated in causing stress corrosion of austenitic stainless steels. On the other hand, the presence of concretes and grouts around the plug and liner may yield an alkaline reaction to the water, and this reaction should mitigate against the aggressive effects of many ions.

Because the temperature of the container surface is hotter than the water contacting it, there is the possibility of evaporation and concentration of residue salts on the container surface. Repeated events of this nature can produce a many-fold concentrated environment next to the container. Of particular concern to the austenitic materials are events that result in chloride ion concentrations on the container surface because of the well-known harmful effects of this species. Similarly, the nitrate ion concentration is a major concern for the copper-base materials. As a point of reference, $\mathrm{J}-13$ well water contains 7 ppm chloride and 10 ppm nitrate. However, the damaging levels of these ions depends on the interactions of many factors: $\mathrm{pH}$, temperature, effects of other chemical species, electrochemical 
potential and so i.1. Determination of damaging levels must be determined experimentally.

Ionizing gamma radiation from radioactive decay of the waste readily penetrates the thin-walled contziner and can cause radiolytic changes in the chemical nature of the environment. The effect of gamma radistion is more important on spent fuel packages than glass packages, and the effect is more pronounced in the earlier part of the containment period when the radiation field is highest. Many of the chemical species formed by radiolysis are quite oxidizing to container materials (ozone, oxygen, oxides of nitrogen, nitric acid, hydrogen peroxide, as well as a number of free radicals). Particularly for the copper-base materials, the effect of these radiolysis reactions increases the oxidation rate and the general aqueous corrosion rate. Also, the radiolysis reactions move the electrochemical potential in the anodic (more positive) direction and the manifestation of this shift in potential favors pitting attack and stress corrosion initiation, particularly for the austenitic materials. Hydrogen is produced by the radiolytic decomposition of water or water vapor; atomic hydrogen is absorbed by many metals, and in susceptible structures (such as martensite in some stainless steels), the hydrogen can cause embrittlement. Obviosuly, thicker containers attenuate the penetration by gamma radiation and decrease concern over radiolytic effects. For the alloys under consideration, approximately each inch of material reduces the gamma dose rate by a factor of ten.

Previous work indicated a potential shift of $150-200 \mathrm{mV}$ at a high gamma dose rate (near $1 \mathrm{Megarad} / \mathrm{hr}$ ) [6]. Work performed at Westinghouse-Hanford showed that the copper-base materials corroded substantially more when irradiated [7], and work at Argonne National Laboratory and reported at this s;mposium indicates that the xidation / corrosion rates vi the copper-base materials is dependent on the humidity of the irradiated environment. This study is also concerned with identification and characterization of the corrosion nroducts in order to make longer term predictions on the prciective nature (or lack of it) of these products.

Most of the vicrk in characterizing the container performance has focused on the exiernal environment, because the container internal environment is believed benign. At the Yucca Mountain surface facility, spent fuel packages could be evacuated and backfilled with inert argon. However, as a result of reacto: performance history, a small number of fuel rrdj "will be "vaterlogged" due to breaches in the cladding. Outgassing of the water from the cladding creates an internal, "moist" environment. It is possible that a container failure could therefore be initiated from inside, such as by radiolytic production of hydrogen in the oxygen-poor environment and subsequent embrittlement of the metal.

As compiled in References 4 and 5, chloride ions provoke stress corrosion cracking (SCC), pitting corrosion, and crevice corrosion on the austenitic materials. AISI 304L stainless steel is the most susceptible of the candidate materials to all three types of corrosion. The molybdenum addition in AISI $316 \mathrm{~L}$ improves its resistance to pitting and crevice attack with no improvement in resistance to SCC. While Alloy 825 is highly resistant to chloride-induced SCC even at high concentrations, the alloy is susceptible to pitting and crevice attack in more concentrated solutions. Work is underway in our laboratory to ascertain the "critical" chloride levels for this material, as a function of $\mathrm{pH}$, temperature, potential, and concentration of other chemical species in the solution. This work follows the example of a study performed on 316 stainless steel to develop a parametric equation in terms of the "critical potential" for breakdown of the passive film as a function of three interactive solution variables (logarithm of the chloride concentration, $\mathrm{pH}$, and temperature) [8]. While chloride 
ion can be damaging to copper and its alloys (usually in conjunction with other ions), the nitrogen-bearing ions (nitrate, nitrite, ammonium) are thr chemical species that exist in the natural environment (or can form in a number of credible scenarios) that are of major concern. A discussion of the chemical concerns and results of previous NNWSI/YM? test result $=$ is available [9].

Finally, among the chemical and environmental cuncerns are the chemical changes that could result from microbiological activity in the near-package environments. Recent disclosures from a number of failure analyses (many in the nuclear power industry) reveal that certain micro-organisms can survive and propagate in environment previously thought to be ishnspitable to these entities. The micro-organisms can remain dormant for long periods of time under unfavorable environments to become active when conditions favor them. The resultant activity of certain well-known kinds of micro-organisms oxidize and reduce the various oxidation states of sulfur and of iron to make the environment more hostile to many r.etals and alloys. Sulfate is present in J-13 weil water, and additional sulfur sources could be introduced during construction and operation. It is speculated that construction of the repository may introduce microbiological organisms through drilling fuids, fuels for powered vehicles, and other human activity. Although the long "thermal" period when the container environment s relatively hot and dry appears not to favor microbiological propagation, their development may be favored in the period when water can re-enter the package environment and the temperature is more conducive. Much work remains for the YMP to evalu: :e scenarios for microbiolugical introduction into the environmeni and what effects their activity would have on the container. There are many hundreds of possible microbiological entities, and since each species lives in and partly creates its own "chemical world", analysis of this problem is complex and requires an multi-disciplinary effort. Furthermore, different species of microbiological organisms may live in consortiums so that ihe metabolism product of one nurtures the propagation of anothe .

\section{CONTAINER MATERIALS SELECTION}

From the above discussio:n, it is obvious that a great number of ccncerns will enter inio selection of the container material that wiil meet the performance objectives. It is evident that the large number of design options and uncertainty of t.ie near-container environment compounds the difficulty of this decision. Nevertheless, a preliminary set of selection criteria has been developed in an effort to make some progress while site characierization and design studies are underwav [10]. The selection criteria are grouped into two broad categories: (1) those related to material performance, and (2) those relatec to fabricability, cost, and other engineering considerations. The material performance factors con prise 70\% of the weighing, while the engineering criteria amount to $30 \%$ of the weighting. These broader criteria are divided into several smaller categories tha; include all of the degradation modes discussed in this paper. Although these criteria were primarily derived for metallic containers (with emphasis on the singie-metal, thin-walled design), they can be extended to oche: kinds of materials and container configurations.

According to a recently prepared plan for the waste package, the selection will occur in stages during 1991-92 before the Advanced Conceptual Design Phas of the waste package and repository begins. Depending on decisions made by the YMP, 
this selectinn can include an expanded candidate list and some preliminary choices of materials and configurations for more robust waste package designs.

\section{TESTING AND PERFORMANCE MODELING}

While the main focus of this paper has been on the performance concerns, $a$ modest effort has begun to resolve some of these concerns. Many of these efforts were mentioned in conjunction with the various concerns. Because there are so many fertures and details about the waste package and repository that are urdecided or cannot be decided until more information is available, the experimental activities are being undertaken in as broadly applicable a way as possible. For instance, the study on determining the critical fitting potential on alloy 825 as an interaction between the solution temperature, $\mathrm{pH}$, and chloride ion content is regarded as a prototype factorial design experiment whose application is much more general. This study also serves as an initial effort to develop empirical performance models. Localized corrosion is a major concers for all candidate materials since crevices cannot be completely avoided. Also, pits and crevices act as sites for stress corrosion initiation. Efforts are underway on experimental technique development aimed at discerning the early stagess of crack initiation and measuring very small crack growth rates. Envii unmental variables, including gamma radiation, in terrelate by changes in the electrochemical potential on the metal surface. Therefore, several performance models will be built $o_{2}$ an electrochemical basis, and testing will be conducted at controlled potentials to accelerate or retard the corrosion phenomernn being considered.

\section{CONCLUSIONS}

A number of performance concerns have been presented and discussed for a container emplaced in a vertical borehole in a repository being considered for Yucca Mountain. Although the YMP has focused primarily on the design of a thin-salled container fabricated from a single metal, the Project is now considering a wider variety of designs and configurations. Some testing and performance modeling work has been initiated to resolve some of the concerns; however, much more work needs to be done in this area.

\section{ACKNOWLEDGEMENTS}

The contributions of many staff members and sub-contract personnel are gratefully acknowledged. The author wishes to thank, in particular, Wi!lis Cla ke and William Halsey for critical review of this paper, and Dennis Fleming for the graphics and computerized typesetting of the manuscript.

\section{REFERENCES}

1. W. E. Glassley, "Reference Waste Package Environment Report", Lawrence Livermore National Laboratory report UCRL-53726 (1986).

2. W. C. O'Neal, D. W. Gregg, J. N. Hockman, E. W. Russell, and W. Stein, "Preclosure Analysis of Conceptual Waste Package Designs for a Nuclear Waste Respository in Tuff", Lawrence Livermore National Laboratory report UCRL-53595 (1984). 
3. R. D. McCright, "An Annotated History of Container Candidate Material Selection", Lawrence Livermore National Laboratory report UCID-21472 (1983).

4. J. C. Farmer, R. D. McCright, and J. N. Kass, "Survey of Degradation Modes of Candidate Materials for High-level Radioactive Waste Disposal Containers", Lawrence Liverniore Laboratory report UCID-21362 (1988).

5. J. C. Farmer and R. D. McCright, "Localized Corrosion and Stress Corrosion Cracking of Candidate Materials for High-Level Radioactive Waste Disposal Containers in the U.S.", Mat.Res. Soc.Symp. Proc, vol 127, 359 (1988).

6. R. S. Glass, G. E. Overturf, R. A. Van Konynenburg, and R. D. McCright, "Gamma Radiation Effects on Corrosion", Cerrosion Science, vol 26, 577 (1986).

7. W. H. Yunker and R. S. Glass, "Long-Term Corrosion Behavior of Copper Base Materials in a Gamma Irradiated Environment", Mat. Res. Soc. Symp. Proc, vol 84, 579 (1987).

8. G. Matamala, "Correlation Model of the AISI 316 Stainless Steel Pitting Potential with Cellulose Bleach Process Variables", Corrosion, vol 43, 97 (1987).

9. R. D. McCright, W. G. Halsey, and R. A. Van Konynenburg, "Progress Report on the Results of Testing Advanced Conceptual Design Metal Barrier Materials under Relevant Environmental Conditions for a Tuff Repository", Lawrence? Livermore National Laboratory report UCID-20144 (1987).

10. W. G. Halsey, "Selection Criteria for Container Materials at the Proposed Yucca Mountain High Level Nuclear Waste Repository", Lawrence Livermore National Laboratory report UCRL-102285 (1989).

Work performed under the auspices of the U.S. Department of Energy by Lawrence Livermore National Laboratory under Contract W-7405-ENG-48.

Prepared by Yucca Mountain Project (YMP) participants as part of the Civilian Radioactive Waste Management Trogram. The Yucca Mountain Project is managed by the Yucca Mountain Project Onice of the U. S. Department of Energy, Las Vegas, Nevada. 